\title{
Vascular Tissue Analysis as a Decisive Tool for Tropical Hardwood Identification: The Case Study of Ekop Species in Cameroon
}

\author{
Pierre Paul Mbarga (D), Armand William Mala, ${ }^{1}$ and Marie Marguerite Mbolo ${ }^{2}$ \\ ${ }^{1}$ IRAD's Multipurpose Station, P.O. Box 592, Abong Mbang, Cameroon \\ ${ }^{2}$ University of Yaoundé I, Faculty of Sciences, Department of Plant Biology, P.O. Box 337, Yaoundé, Cameroon
}

Correspondence should be addressed to Pierre Paul Mbarga; pierrepaul.mbarga@gmail.com

Received 19 January 2020; Accepted 12 March 2020; Published 8 April 2020

Academic Editor: Qing-Lai Dang

Copyright (c) 2020 Pierre Paul Mbarga et al. This is an open access article distributed under the Creative Commons Attribution License, which permits unrestricted use, distribution, and reproduction in any medium, provided the original work is properly cited.

\begin{abstract}
The perforation plates and vessel-ray pitting of tropical hardwoods are typical features that make it possible to mark species within a botanical family. This study aims to bring out a consistent and robust framework for a clear distinction through anatomical features among various Ekop woods based on usual nomenclature on trade. Perforations plates and vessel-ray pitting are determining components for the classification of the species. Indeed, several species exploited under the trade name Ekop because of their grain, color, and wooden decoration patterns do not belong to the same taxonomic class. With the natural structure of cells and their intervessel pits observed in xylem and phloem, it appears that the perforation plates and the vessel-ray pitting are decisive components for the classification of Ekop species. Forty-three wood specimens of Ekop were collected from forests in Ebolowa, Mbalmayo, and Abong Mbang. In addition, 155 microscopic sections of Ekop slides with at least 3 representatives of identified species were observed. Thus, macroscopic observations through a hand magnifying glass were performed on wood carrots. Then, the microscopic sections of slides in the first 63 features of the International Association of Wood Anatomists list were analyzed. Correlations were observed between vessels elements and other main features through component analysis. Four groups of Ekop were differentiated by gathering in each genus a matrix of similar features across their vessels groupings, perforation plates, and vessel-ray pittings. A tabular key was used to further define the identity of the Ekop species. This study makes it possible to recognize Ekop wood beyond the dendrological aspects of vegetative and reproductive organs. Finally, a few typical features used for a precise demarcation were identified, for a taxonomic classification within the Ekop group.
\end{abstract}

\section{Introduction}

According to ITTO [1], timber production in tropical Africa increased from 2012 to 2017 reaching 6.7 million $\mathrm{m}^{3}$ in 2015. Cameroon was the third largest exporter of tropical timber and the first producer in tropical Africa with 1.2 million $\mathrm{m}^{3}$ in 2015 [2]. This trend was accentuated with the allocation of logging concessions to Asians, who were interested in other little known timbers during the period 2004 to 2012. Thus, species in the decline like Ekop have benefitted from the favorable trade opportunities. Therefore, the revaluation of their free board taxable value reaching 85,450 CFAF (131 Euros) $/ \mathrm{m}^{3}$ has increased the price of some high timber species [3].

Five species, including Tetraberlinia bifoliata $\left(25,000 \mathrm{~m}^{3}\right)$, accounted for $72 \%$ of total $\log$ exports in
Cameroon. Among them, 10 Ekop species represented $19.23 \%$ of the total volume during 2015 and 2016 with Julbernadia pellegriniana (12\%), Brachystegia cynometroides (5.5\%), and other Ekop species (1.73\%) of export logs appearing on national statistics [3].

The name Ekop comes from Bantu's ethnic languages covering the Fang-Beti-Bulu cultural area and is used by forest timber prospectors in South and Center regions. The practices of ethnotaxonomy among the people of CenterSouth Cameroon are based on a rich heritage with a knowledge of the useful plants that have not been formally codified [4].

Letouzey and Mouranche [5] chose the pronunciation Ekop (read Ekaup) from native forest timber prospectors to signify a group of trees identifiable by a common external 
character. It is characterized of a smooth or hard bark, which is easily detachable with a cutlass. Also, there is a fibrous "skin" contiguous that can be removed from the inner side [6]. They refer to species belonging to about fifteen genera of Leguminosae-Caesalpinioideae family according to Association Technique Internationale des Bois Tropicaux [7]. The local name Ekop better defines pilot names to distinguish various species exported under this market label [8]. In Cameroon, logging companies exploited a set of diverse Ekop species based on their morphological appearance, not their botanical classification [5]. Indeed, these species have a clearly transferable taxonomical identity [9]. For example, in Gabon, a trial conducted on the identification of the Ekop or Andoung species complex in nine forest concessions showed that only $11 \%$ corresponded to the described botanical species [10].

Therefore, the recognition of such species only based on vegetative and reproductive organs (leaves, flowers, and fruits) has proven difficulties [11]. Moreover, the masses of sawn timber make their recognition more difficult to give credibility to the identification. In the timber market, similarities are striking among Ekop woods due to dendrological appearances and lead to confuse the real name of species [12]. Thus, it is essential to confirm with other identifying criteria using wood features [13]. Some initial works showed that vessel-ray pitting and perforation plates are decisive to emphasize similar features on species. So, an analysis of the discriminating features showed a tiny morphological difference of cell arrangements [14].

In Cameroon, Ekop includes at least 15 genera and 135 species present in various forest ecosystems. The species are characterized by morphological similarities of woods [7]. The issue remains on the consistency in describing the typical features of vessels in order to define a tabular key for these species [15]. One way to fix this problem is to take into account the wood structure of Ekop showing a remarkable porosity, typical coloring, a high presence of nonseptate fibers, and alternate or polygon pits in most species [16]. Indeed, these typical features described by the International Association of Wood Anatomists list have been decisive for grouping and characterizing them based on their microscopic section analysis [17].

This study aims to bring out a consistent and robust framework for a clear distinction among various Ekop species through anatomical features of this group.

Specifically, the study's target was to

(i) Identify the vessels, tracheid, and fiber designs of the Ekop species

(ii) Create a referential index for the categorization of Ekop groups

(iii) Establish precise demarcation features allowing a taxonomic classification within the Ekop group

\section{Materials and Methods}

\subsection{Material}

2.1.1. Study Site. The study was carried out in Cameroon from February to August 2017 in the geographical area of the moist and semideciduous forest, which is identified as Ekop's area of occurrence in Cameroon [5]. The study site is located between latitudes $2.31^{\circ}$ and $5.79^{\circ}$ North and longitudes $8.94^{\circ}$ and $16.1^{\circ}$ East (Figure 1). The species in this area are mostly endemic and characterize the Biafra forest [18].

2.1.2. Presentation of Physical Material. Two types of wood samples have been studied: trunk fragments taken from duramen on alive trees or logs and microscopic sections on wood slides. These Ekop samples came from forestmanaged units in nearby localities and in some local forests around Mbalmayo and Abong Mbang. This was harvested using a dendrometrical auger. We prepared each fragment in $01 \mathrm{~cm}^{3}$ of wood with $20 \mathrm{~mm}$ cylindrical section after perforating standing trees georeferenced or on timber located at the Cameroon United Forests park at Ebolowa.

For each species collected, we prepared slides to read anatomical profile. 155 microscopic sections were realized to describe anatomical features of our sample.

\subsection{Methods}

2.2.1. Sampling Design. The various dendrological and xylographic sheets on Cameroon flora were used to designate the selected species of Ekop [19]. The sampling of the species was defined according to the stand distribution and logging map of Ekop (Figure 1). A randomized sampling with 3 repetitions was used. Forty-three samples $(n=43)$ of collected specimens representing at least three species of each of the fifteen genera studied were examined.

\subsubsection{Data Collection}

(1) Identification of Ekop Anatomical Features. For polished trunk fragments, a $10 \mathrm{X}$ magnifying glass was used in to characterize the primary arrangements of the cells on wood fragments obtained from the samples. The pieces of wood obtained were shaped using a thin steel blade soaked in ethanol (30\%) and saw to obtain the three woody planes. The slides with microscopic sections obtained were compared with Insidewood's online databases and the Tervurenwood wood collection of these species [17]. The observation of sections on slides with a microscope was done according to the manual of the International Association of Wood Anatomists [20]. Focus was on the recurring reading of the first sixty-three basic anatomical features.

(2) Categorization of Ekop Specimen. When obtaining major features of studied specimens and authenticating the typical traits of many Ekop species, we separated out characters to allow a classification in a referential index. The purpose was to compare observations of all features made on material cores with those obtained on reference databases. Thus, specific traits were analyzed for a given species by eliminating one alternate variable of the same feature. Finally, a 


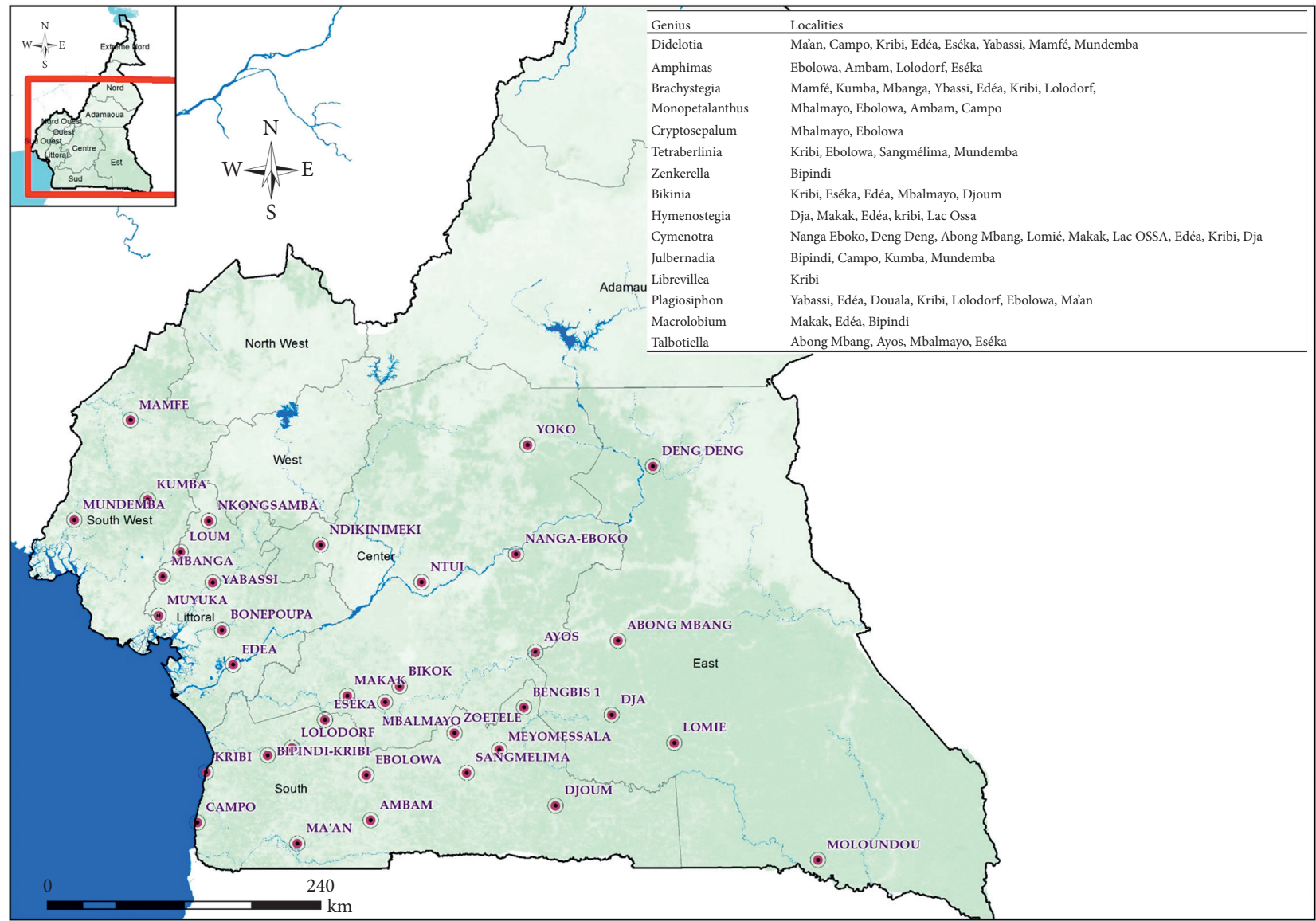

○ Locality

Water

Region boundary

Limit of Cameroun

\section{Vegetation \\ High density \\ Low density}

Figure 1: Distribution of Ekop species in Cameroon (adapted from [18]).

tabular key describing the wood grain, streaks, and color was described for these species.

(3) Taxonomic Classification of Ekop Group. The General Nomenclature of Tropical Timber in its $7^{\text {th }}$ edition was the reference book used to define common pilot names for forest loggers [21]. On this system, the trade description of species corresponds to the specific scientific names. Based on that, the scientific name applies to a species which is in accordance with the botanical features and its wood anatomy. The rules of classification in various families are those of the systematics (APG III genetic classification). Some earlier families are classified into new ones based on phylogenetic affinities, based on the dendrological aspects, but not strictly match up with others on the distinguish features [22].

2.2.3. Statistical Analysis. Two hundred forty-three (243) observations focused on typical features of vascular tissue in various Ekop species were used to compare similar microscopic features at different levels [23]. For Ekop species, a total of 41 of the 163 major features on the International Association of Wood Anatomical features records were decisive in this study. The data obtained were processed by the multivariate analysis procedure with two projections from SPSS software (version 16.0.) for correlations between Ekop specimens. Pearson's chi-square $\left(\chi^{2}\right)$ test was applied to validate the qualitative variables obtained. A tabular key that came down by elimination of similar features allowed us to classify the various Ekop groups [24].

\section{Results}

3.1. Characterization of the Ekop Microscopic Features. We worked on 43 Ekop species belonging to 15 genera with typical features on their wood (Figure 2). Eighty-five percent of species in this sample came from Southern Cameroon with a high potential timber. The remaining fifteen percent came from Center and Eastern regions with low density. The analysis of the microscopic sections described for Ekop species shows the variable features on the vascular tissue. For 


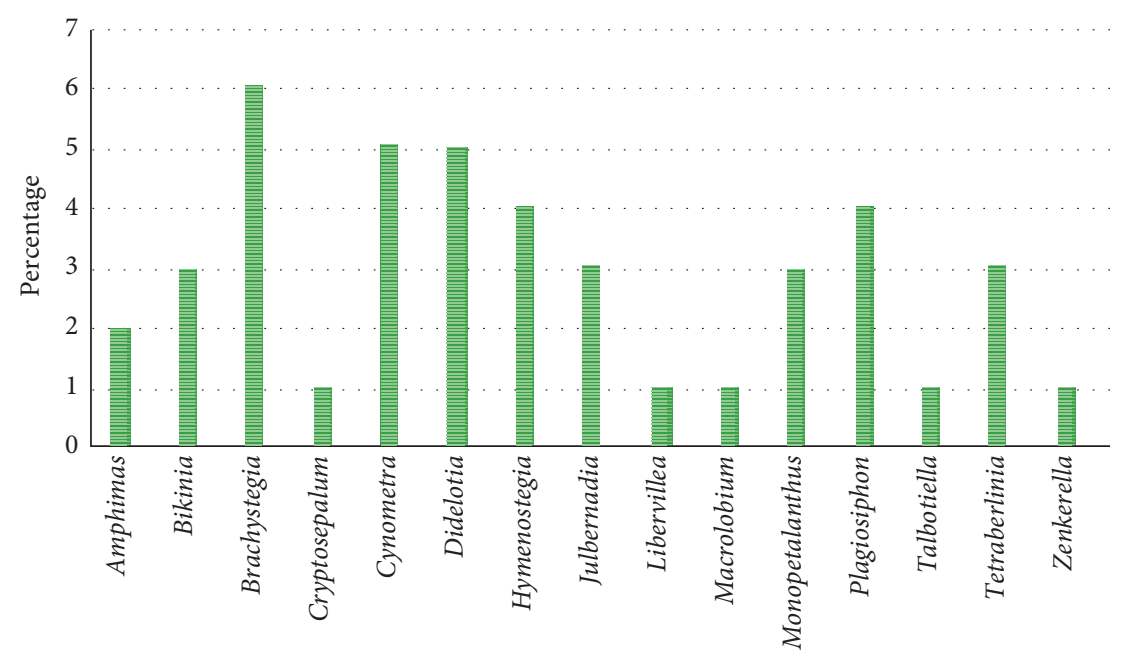

Ekop genus

Figure 2: Main Ekop genus collected in Cameroon.

each genus, there is a typical trait representing a marker of many species. The parenchyma cells are observable and the vessels abundant, the diffuse structure, and common apotracheal axial parenchyma are some of the major characteristics. For ninety-five percent of the sample, the size of the intervascular pits, the length of the fibers, the thickness of the walls, and the presence of the crystals of calcium oxalate and siliceous corpuscles in the parenchyma are visible. An axial parenchyma arrangement was found in three forms, and there was the presence of deposits in some cells. This parenchyma although marginal as in Brachystegia laurentii is not considered as growth rings.

3.2. Development of a Referential Index for Ekop Species. The sections obtained from Ekop species showed specific anatomical features with regards to the vessel arrangement and size in accordance with the sixty-three first features of the International Association of Wood Anatomists list. For forty-one parameters, we found typical features of vascular tissue of various Ekop species. Considering perforations plates and vessel-ray pitting, a demarcation is deeply accentuated for main features on various species. There are specific marks on perforation plates that make a difference on various Ekop species in terms of arrangement and size. Observations showed that vessel elements were decisive for development of a referential index. The case of Tetraberlinia $\mathrm{sp}$ is well illustrated for these features with outstanding pits compared to other types studied (Figure 3).

3.3. Taxonomic Grouping of Ekop. Several similarities were observed among the Ekop group. Focusing on the arrangement of the vessels and the porosity of the wood, we categorized four groups based on their genus. Many anatomical features such as vessel arrangement, length, and associated elements left some appearance patterns. An analog frame was proved between Tetraberlinia-Jubernadia, Brachystegia-Cynometra, and Hymenostegia-Cynometra,

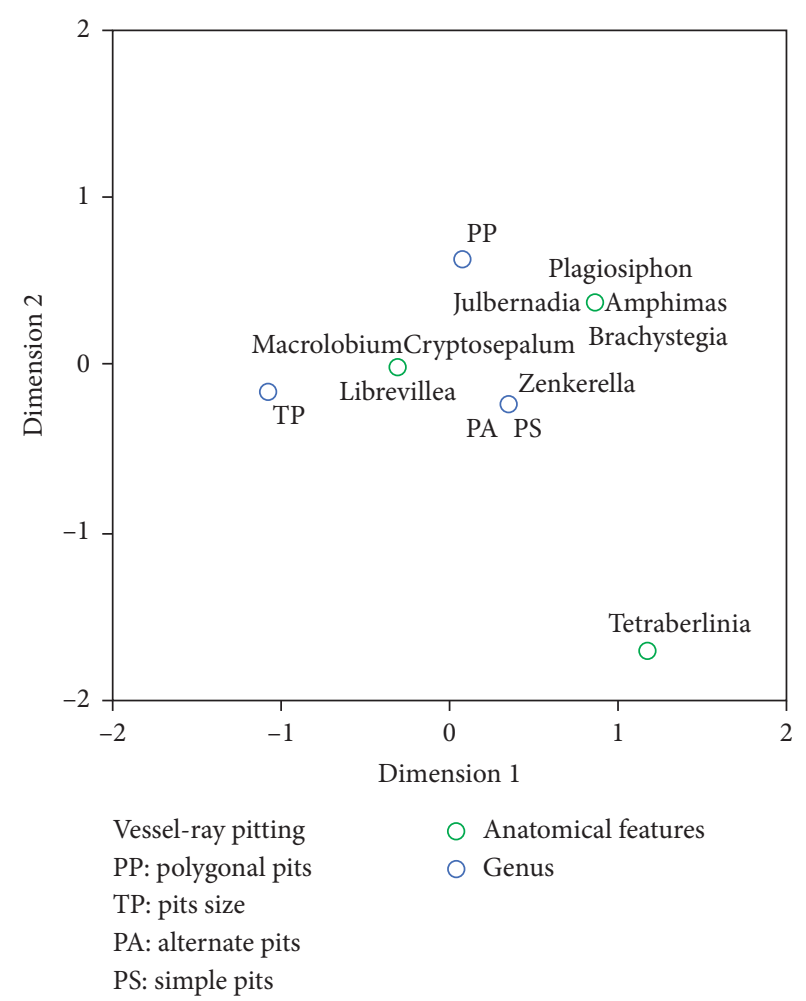

FIGURE 3: Setting of vessel-ray pitting within Ekop's genus.

while Bikinia are closer to Aphanocalyx. Considering the level of affinity between various genera, we obtained major correlations between the values of the mass with regard to the grain. Four values were obtained to classify Ekop species in many groups. Tetraberlinia showed a remarkable difference with the other genera (Table 1).

Finally, the fifteen genera were grouped in order to recognize Ekop species with similarities to one another on microscopic features and nearest technological properties (Table 2). A categorization based on physical resemblance of 
TABLE 1: Values of the mass coefficient of various genera.

\begin{tabular}{|c|c|c|c|}
\hline \multicolumn{4}{|c|}{ Confidence row points } \\
\hline \multirow{2}{*}{ Genus } & \multicolumn{2}{|c|}{ Standard deviations } & Correlation \\
\hline & 1 & 2 & $1-2$ \\
\hline Macrolobium & 0.071 & 0.058 & 0.137 \\
\hline Zenkerella & 0.071 & 0.058 & 0.137 \\
\hline Librevillea & 0.071 & 0.058 & 0.137 \\
\hline Cryptosepalum & 0.071 & 0.058 & 0.137 \\
\hline Monopetalanthus & 0.071 & 0.058 & 0.137 \\
\hline Bikinia & 0.071 & 0.058 & 0.137 \\
\hline Brachystegia & 0.257 & 0.101 & -0.595 \\
\hline Julbernadia & 0.257 & 0.101 & -0.595 \\
\hline Plagiosiphon & 0.257 & 0.101 & -0.595 \\
\hline Tetraberlinia & 1.080 & 0.665 & 0.847 \\
\hline Amphimas & 0.257 & 0.101 & -0.595 \\
\hline Didelotia & 0.071 & 0.058 & 0.137 \\
\hline Cymenotra & 0.071 & 0.058 & 0.137 \\
\hline Talbotiella & 0.071 & 0.058 & 0.137 \\
\hline Hymenostegia & 0.071 & 0.058 & 0.137 \\
\hline
\end{tabular}

TABle 2: Taxonomic grouping of Ekop for market used.

\begin{tabular}{lcc}
\hline Closed genus & Similar species & Typical pilot names \\
\hline Tetraberlinia and Julbernadia & $\begin{array}{l}\text { Tetraberlinia bifoliolata } \\
\text { Julbernadia bifoliolata }\end{array}$ & Ekaba, Ribi \\
\hline Plagiosiphon, Macrolobium, and Talbotiella & $\begin{array}{c}\text { Plagisiphon multijugus } \\
\text { Talbotiella batesii }\end{array}$ & $\mathrm{G}$ \\
& Macrolobium brachystegioides & Ekoussek \\
Hymenostegia, Brachystegia, Cynometra, Zenkerella, & Brachystegia mildbreadii & Naga \\
and Librevillea & Didelotia afzelii & Ekop evène \\
& Julbernadia seretii & Nganga \\
\hline Didelotia, Bikinia, Amphimas, Cryptosepalum, and & Cynometra hankei & Mayo or b (Pink \\
Monopetalanthus & Didelotia brevipaniculata, Bikinia letestui, & Andoung) \\
\hline
\end{tabular}

vascular tissues acting on mechanical and technological properties (density and Monnin hardness) resulted in four groups.

\section{Discussion}

The diversity on Ekop microscopic features allowed us to ascertain the identity of Ekop wood. There are typical arrangements of perforation plates and vessel-ray pitting. Indeed, the major features are similar to at least $95 \%$ with nevertheless 3 nonidentical features considered as markers in some genera. Eighty-five percent $(85 \%)$ of species observed came from Southern Cameroon. Finally, in Ekop, the wood structure is marked by a high presence of nonpartitioned fibers and alternate or polygon punctuations in most species. These results are consistent with those given in [22] or studies on Bikinia, Aphanocalyx, and Tetraberlinia [25].

Within the genus studied, the secondary dendrological features of the target species integrated into this wood identification process improve its reliability. Thus, Tetraberlinia, which belongs to whitish Ekop, has markers similar to the species considered as reddish Ekop. For each genus, there are typical features representing markers of that which confirms the diversity of their woods as described in [26].

The vessels arrangement and intervessel pits show many similarities among the four groups. Indeed, the genus Monopetalanthus is so close to Bikinia because of the biochemical characters unusual in Aphanocalyx and Tetraberlinia [27]. This difference is more noticeable in Tetraberlinia and much less in Aphanocalyx. Most of these species are endemic with well-known conservation status. Differentiating species within the Ekop group appeared to be a complex process, given many similarities between them. An analysis of both observed trunk fragments using a hand magnifier and microscopic sections of the wood slides resulted in the classification of four groups of Ekop. The determination of these species is based on the statistical analysis of typical features of the vessel-ray pitting and arrangement. Indeed, the microscopic analysis of wood features was necessary and a complementary approach for an efficient identification of Ekop species. Thus, the description of the vessels grouping provides more details on the typical features and makes it possible to focus clearly on 
the taxonomic identity of Ekop. Finally, constructing a tabular key for Ekop classification is important for eliminating some confusions in identification based on their physical observation.

\section{Conclusion}

The study aimed to bring out a consistent and robust framework for a clear distinction between various Ekop species. The findings reveal that various typical traits, such as parenchyma cells or perforations plates and vessel-ray pitting, represent markers of many Ekop species. Then, there are typical features especially on vessel elements which are decisive for development of a referential index. Finally, a classification learning on vessels structure and wood porosity helps to desegregate four main groups of Ekop genus.

Parenchyma and vessels showed typical features allowing us to clearly separate Ekop species. It appeared as three forms of axial parenchyma arrangement. Based on perforation plates and vessel-ray pitting, we developed a referential index for the categorization of Ekop groups. Observed similarities among the Ekop genera and markers allowed four taxonomical classification groups.

Many anatomical features such as vessel arrangement, length, and associated elements left some appearance patterns. An analog frame was proved among the Ekop group due to physical resemblance and mechanical and technological properties.

In Cameroon, 135 Ekop species were found in various forest ecosystems. An analysis of wood features showed slight differences in morphological appearance. The confusion made on wood market was resolved by the description of typical features especially parenchyma and vessels with a defined tabular key of these species.

These results also permit the traceability of these timbers and better preservation of their threatened species of Ekop.

\section{Data Availability}

The work submitted to your appreciation is original and the data were obtained following several Research missions. Analysis of these data gave the results presented in this article.

\section{Conflicts of Interest}

The authors declare that they have no conflicts of interest.

\section{References}

[1] ITTO, Biennal Review and Assessment of the World Timber Situation 2015-2016, p. 224, ITTO, Yokohama, Japan, 2017.

[2] D. Mahonghol, S. Ringuet, J. Nkoulou, O. G. Amougou, and H. K. Chen, Les Flux et les Cir1cuits de Commercialisation du Bois: le Cas du Cameroun, p. 122, TRAFFIC. Yaoundé, Cameroun et Cambridge, Royaume-Uni, 2016.

[3] MINFOF, "Esquisse d'une analyse statistique des spécifications annuelles des produits forestiers au port de Douala," MINFOF, Yaounde, Cameroon, Rapport COMCAM, 2016.
[4] J. M. Onana and P. Mezili, "Receuil des noms de plantes en langues ethniques de cultures de la forêt du Cameroun," Une Contribution de la Botanique à la Valorisation Dessavoirs Traditionnels, Vol. 44, Universitaires Européennes, Saarbrücken, Germany, 2012.

[5] R. Letouzey and R. Mouranche, Ekop du Cameroun, p. 101, CTFT, Nogent-sur-Marne, France, 1952.

[6] J. Gérard, D. Guibal, J. C. Cerre, and S. Paradis, Atlas des Bois Tropicaux: Caractéristiques Technologiques et Utilisations, QUAE, Versailles, France, 2016.

[7] P. Détienne, "Du nouveau chez les Andoung," Bois et Forêts des Tropiques, vol. 267, no. 1, pp. 101-103, 2001.

[8] F. Pellegrin, "Les «Gombé» du cameroun," Bulletin de la Société Botanique de France, vol. 100, no. 7-9, pp. 266-267, 1953.

[9] A. Aubréville and J. F. Leroy, Flore du Cameroun. Légumineuses-Césalpinioidées

(Leguminosae-Caesalpinioideae), p. 339, Muséum National d'Histoire Naturelle, Paris, France, 1970.

[10] R. Mboma, "Caractérisation des essences forestières pour une gestion durable des ressources en Afrique centrale: le CAS des andoung au gabon,” MNHN, Paris, Italy, 2012.

[11] D. Normand and J. Paquis, "Manuel d'identification des bois commerciaux," Tome 2. Afrique Guinéo-Congolaise, p. 337, Centre Technique Forestier Tropical, Nogent-sur-Marne, France, 1976.

[12] D. Louppe, A. A. Oteng-Amoako, and M. Brink, Ressources Végétales de l'Afrique, p. 785p, Backhuys, Wageningen, Netherlands, 2008.

[13] E. Bolza and W. G. Keating, African Timbers: The Properties, Uses and Characteristics of 700 Species, p. 710, Division of Building Research, CSIRO, Melbourne, Australia, 1972.

[14] P. Groenendijk, U. Sass-Klaassen, F. Bongers, and P. A. Zuidema, "Potential of tree-ring analysis in a wet tropical forest: a case study on 22 commercial tree species in Central Africa," Forest Ecology and Management, vol. 323, no. 1, pp. 65-78, 2014.

[15] C. Wiemann, "Hand-lens key for the identification of west African woods," Journal of Tropical Forest Science, vol. 6, pp. 451-488, 1992.

[16] H. G. Richter and M. Oelker, Macroholzdata: Commercial Timbers: Descriptions, Illustrations, Identification, and Information Retrieval, Federal Research Centre for Forestry and Forest Products, Hamburg, Germany, 2002.

[17] P. Kitin, S. Du, B. Kirchoff, and H. Beekman, Visual Identification Key for 38 Central African Woods-Onwards, p. 28, Royal Museum for Central Africa, Tervuren, Belgium, 2011.

[18] J. Vivien and J. J. Faure, Arbres des Forêts Denses d'Afrique Centrale, p. 945, Nguila Kerou, Clohars Camoet, France, 2011.

[19] J. M. Onana and M. Cheek, The Red Data Book of the Flowering Plants of Cameroon, p. 578, Royal Botanic Garden, Kew, UK, 2011.

[20] E. A. Wheeler, P. Baas, and P. E. Gasson, "List of features for hardwood identification. International Association of Wood Anatomists list of features for hardwood Identification," IAWA Bulletin, vol. 10, no. 3, pp. 219-332, 1989.

[21] J. C. Claudon, P. Detienne, J. L. Doucet, E. Groutel, A. Lebedys, and M. Vernay, La Nomenclature Générale des Bois Tropicauxp. 152, 7th edition, CPI Books, Chatham, UK, 2016.

[22] Q. Meunier, C. Moumbogou, and J.-L. Doucet, Les Arbres Utiles $d u$ Gabon, p. 340, Les Presses Agronomiques de Gembloux, Gembloux, Belgium, 2015. 
[23] A. Takahashi, Compilation of Data on the Mechanical Properties of Foreign Woods (Part 3) Africa, Shimane University, Matsue, Japan, 1978.

[24] C. M. Wilks and Y. A. Issembe, "Guide pratique d'identification: les Arbres de la Guinée equatoriale région continentale,” p. 546, CUREF, Bata, Guinée Équatoriale, 2000.

[25] J. J. Wieringa, Monopetalanthus Exit: A Systematic Study of Aphanocalyx, Bikinia, Icuria, Michelsonia and Tetraberlinia (Leguminosae, Caesalpinioideae), p. 320, Wageningen Agricultural University, Wageningen, Netherlands, 1999.

[26] D. Normand, "Ekop ou Andoung, une des essences intéressantes à retenir," Bois et Forêts des Tropiques, vol. 26, pp. 381-388, 1952.

[27] C. K. Geoffrey and J. J. Wieringa, "Hydroxypipecolic acids and hydroxyprolines as chemical characters in Aphanocalyx, Bikinia and Tetraberlinia (Leguminosae: caesalpinioideae): support for the segregation of Monopetalanthus," Biochemical Systematics and Ecology, vol. 31, no. 3, pp. 279-292, 2002. 